\title{
Close Encounters: Minority and Majority Perceptions of \\ Discrimination and Intergroup Relations in Antwerp-Belgium
}

\author{
Alanya, Ahu, Swyngedouw, Marc, Vandezande, Veronique, Phalet, Karen \\ University of Leuven, Belgium
}

Accepted for publication in International Migration Review

\begin{abstract}
(130 words)
Increasing numbers of second-generation Muslims are highly qualified and locally embedded in today's European cities. This does not protect them, however, from experiencing discrimination in intergroup encounters in school, at work, or in the street. Taking an approach from local intergroup relations between ethnic minorities and the majority society, and drawing on the TIES surveys ('The Integration of the European Second generation') of Turkish and Moroccan Muslims and majority Belgians in Antwerp-Belgium, our research aims (a) to establish minority and majority perspectives on (reverse) personal discrimination, (b) to explore perceptions of discrimination in different life domains, and (c) to differentiate further between gender, socio-economic attainments, and local climates. Structural equation models relate minority and majority perceptions of discrimination to gendered and situated intergroup encounters in socio-economic and civic domains of life.
\end{abstract}




\section{INTRODUCTION}

Discrimination has been advanced as a plausible explanation of persistent ethnic minority disadvantage in the second generation. ${ }^{1}$ In particular, the children of Muslim immigrant workers from Turkey and Morocco are among the most disadvantaged minorities in the North-West of Europe (Heath, Rothon and Kilpi, 2008). In spite of overall disadvantage, increasing numbers of local-born Muslim citizens are socio-economically successful and locally embedded in their highly diverse urban neighborhoods. Yet, this does not protect them from experiencing discrimination in their daily encounters with the majority society (Voas and Fleischmann, 2012). Looking beyond ethnic disadvantage, therefore, we ask the question how often and in which life domains both minority and majority citizens in today's European cities perceive discrimination, for instance in the workplace, in school, in their neighborhood, or when going out...

Against the backdrop of a hostile public opinion climate against Muslim minorities across Europe (Van Acker, 2012; Van Dijk, 2000), we define perceived personal discrimination as the experience of unequal or hostile treatment in situated intergroup encounters. We propose a contextual approach from the ways intergroup relations are structured along ethnic, religious, gender and class lines in particular life domains and in local intergroup contexts. There is cross-national evidence of pervasive discrimination in intergroup relations between Muslim minorities and European majorities (Voas and Fleischmann, 2012). Importantly, the experience of discrimination is not restricted to the most disadvantaged minority group members. As members of a devalued minority group, also economically successful Muslims report negative intergroup contacts and attitudes (Dixon, Durheim,

\footnotetext{
${ }^{1}$ We are aware of the fact that children of immigrants, born and raised in the majority society, are already part of the society. Therefore it is more appropriate to call them first generation nationals with Turkish or Moroccan ancestry than second-generation immigrants. However, we continue to use the conventional term 'second generation' (Portes and Rumbaut 2001; Alba and Waters 2011) in this paper.
} 
Tredoux, Tropp, Beverly and Eaton, 2010; Ten Teije, Coenders and Verkuyten 2012). Similarly, perceived discrimination is not restricted to minority group members. From an intergroup relations perspective, also nominal majority group members may perceive socalled "reverse discrimination" (Kluegel and Bobo, 2001). Majority perceptions of reverse discrimination refer to feelings of intergroup competition or threat, when minorities are seen to encroach upon exclusive majority entitlements, for instance, to the better schools, jobs or houses in the city, or when they are locally outnumbering the majority in highly diverse 'majority minority' urban neighborhoods (Rink, Phalet and Swyngedouw, 2008; Swyngedouw, Phalet and Deschouwer, 1999).

The present research aims to contextualize perceived discrimination from different group perspectives on situated intergroup interactions in different life domains. To this end, we examine the perspectives of Muslim minorities and local majorities in the multicultural city of Antwerp-Belgium as a deeply divided local intergroup context. The research has a threefold aim. First, we aim to establish levels and grounds of perceived discrimination across Turkish and Moroccan Muslim minorities and majority Belgians in Antwerp. Though majority perceptions of reverse discrimination are less researched, they are part and parcel of intergroup relations in today's multicultural cities, where the national majority population can be a local minority. The second aim is to look beyond perceived unequal treatment in the socio-economic domain of school and work, and to distinguish between different life domains. For instance, discriminatory intergroup contacts with neighbors, when going out, and with the police are less directly linked to socio-economic disadvantage, and hence less studied in quantitative surveys. Still, such negative contact experiences powerfully define the quality of local intergroup relations, also for economically successful minority or nominal majority members. Thirdly, we aim to differentiate further within increasingly internally diverse Muslim minorities, and also within the majority group. We add to previous research 
by zooming in on friendly or hostile local intergroup climates as proximal determinants of perceived discrimination. And we extend a binary approach of minority-majority intergroup relations to take into account intersectionality with gender and social class (i.e., socioeconomic attainment).

Regardless of how accurately minority and majority perceptions reflect actual discriminatory treatment, they merit our research attention because of their social and behavioral consequences, for instance for minority health and well-being (Pascoe and Richmand, 2009) and for political attitudes and action (Fleischmann, Phalet and Swyngedouw, 2013). On the minority side of second-generation Muslims, there is solid evidence of actual discrimination in European labour markets (for experimental evidence, cf. Amadieu, 2004; Zegers de Beijl, 2000; for statistical evidence, cf. Blank, Dabady and Citro, 2004; Holzer and Ludwig, 2003; Yinger, 1998; in Belgium: Castelain-Kinet, Es-Safi, Feld and Lannoy, 1998; Martens et al., 2005; Phalet, 2007; Phalet and Heath, 2011). Moreover, perceptions of discrimination were indeed found to predict lower socio-economic attainment (Heath and Li, 2007; Silberman, Alba and Fournier, 2007; Reitz and Bannerjee 2007). Still, self-reported discrimination may over- or underestimate the frequency of actual discrimination against minorities, for instance, when minority members fail to identify discriminatory impact of engrained practices in the absence of direct discriminatory treatment or intent (Simon, 2005). On the majority side, associations with actual discrimination may be even more tenuous. Typically, majority perceptions of discrimination arise from feelings of threat to the status quo in competitive or otherwise tense intergroup relations with devalued minorities (Rink, Phalet and Swyngedouw, 2008).

To assess perceived discrimination, we make use of the TIES ('The Integration of the European Second generation') surveys of Turkish and Moroccan second-generation samples and a majority comparison sample in the same urban areas in the city of Antwerp-Belgium. 
Antwerp is a world port and home to large numbers of immigrant workers and their families, including significant Turkish and Moroccan communities. Local intergroup relations in Antwerp are marked by a strong anti-immigrant and anti-Muslim sentiment and vote, as political leaders and parties are capitalizing on popular feelings of threat or competition. As such, the local intergroup context in Antwerp exemplifies increased tension and public hostility against Muslim minorities in many European migration contexts.

\section{THEORETICAL EXPECTATIONS}

\section{Minority and Majority Group Perspectives}

Our first research aim was to establish minority and majority group perspectives on discrimination. Against the background of strained intergroup relations between Muslim minorities and the local majority population of Antwerp-Belgium, we examine perceived levels and grounds of personal discrimination on both sides of the intergroup divide. Minority and majority experiences of intergroup relations have mostly been studied in separate research streams on ethnic disadvantage and prejudice respectively. On the one hand, large-scale crossnational survey research documents persistent and often pervasive majority prejudice against immigrant minorities (Meuleman 2011, Rustenbach 2010). On the other hand, special minorities surveys have documented minority perceptions of discrimination (e.g., Portes and Rumbaut, 2001; Swyngedouw, Phalet and Deschouwer, 1999).

We conceive of minority and majority perceptions of discrimination as two sides of unequal and often hostile intergroup relations between Muslim minorities and local majorities. From a minority perspective, perceived discrimination refers to their subordinate group position as low-status or devalued group members. Their subordinate group position implies that they are more likely overall to become a target of unfair or hostile treatment and less protected from adverse consequences of such treatment than the majority. In Steele's 
(2010) terms, they are socialized to anticipate a different set of 'identity contingencies' than majorities in their day-to-day intergroup interactions. Conversely, from a majority perspective, so-called reverse discrimination arises from feelings of threat to their dominant group position as majority members, which can be attributed to a 'threatening' minority. Majority feelings of threat should be understood against the backdrop of the societal 'ethnic hierarchy', which endows majorities with more access to economic and cultural resources and with more political power and social protection than minorities (Blumer, 1958; Bobo, 1988). From a majority perspective, therefore, intergroup threat refers to the actual or perceived power of numbers in local 'majority minority' settings (Quillian, 1995; Rink et al., 2008), to economic competition over scarce resources such as housing or jobs with minorities (Coser, 1956; LeVine and Campbell, 1972; De Rycke, Swyngedouw and Phalet, 1999; Scheepers, Gijsberts and Coenders 2002), or to perceived culture conflict between different values and ways of life (Voas and Fleischmann, 2012; Van Acker and Vanbeselaere, 2011).

The present study focuses on perceived discrimination among second-generation Muslims and majority Belgians in Antwerp as local intergroup context. We ask how frequently they experience discrimination and on what grounds. Moroccan and Turkish Muslims are at the bottom end of a quasi-consensual ethnic hierarchy as most devalued minorities, i.e., structurally disadvantaged, socially distant, and negatively stereotyped as 'culturally deviant' (Hagendoorn, 1995; Phalet and Gijsberts, 2007). Both religion and ethnic origin constitute 'bright boundaries' which separate Turkish and Moroccan Muslims from the majority population in European societies (Alba, 2005). Moreover, Moroccans tend to be the most stigmatised minority group as prototypical Muslims and 'Arabs' (see Table 1). Accordingly, majority participants in TIES evaluated their in-group most positively, the Turkish minority less, and the Moroccan minority least positively. Arguably, overall levels 
and grounds of perceived personal discrimination in our study will reflect general evaluative distinctions along ethnic and religious lines.

[Table 1 about here]

\section{Different Life Domains}

Our second research aim was to explore perceived personal discrimination in different life domains. With increased ethnic diversity in contemporary societies, social relations connecting fellow citizens have increasingly also become intergroup relations. From an intergroup relations perspective, perceived discrimination may arise in any social or institutional context where minority and majority groups meet and interact. Our study extends the scope of perceived discrimination beyond most researched socio-economic domains to other life domains. Other domains include hostile intergroup encounters with fellow citizens in one's neighbourhood or in other public spaces, or with the police as representing public authority. These latter domains account for significant portions of racist incidents reported by minorities (for Belgium: CGKR annual report 2012). For instance, especially Muslim men are frequently targeted for identity checks on the street or when going out (FRA 2007; Russell, Quinn, Riain, and McGinnity, 2009; Feagin, 1991). Importantly, economically successful minority members may well escape discrimination at work, but they can still become targets of discriminatory identity checks by the police, depending on where they live and where they go out in the city. Finally, also majority members may experience discrimination in negative intergroup contacts with minority neighbours or in their free time.

Since large-scale minorities surveys have mainly focused on explaining socio-economic disparities (Simon, 2005), they typically use thin measures of perceived discrimination (usually single indicators). These measures gloss over possible variation across different life 
domains (for exceptions, see Hebl, Foster, Mannix and Dovidio, 2003; Swim, Johnston and Pearson, 2009; Maxwell, 2014). Our study adds to this literature by including experiences of hostile or unfair treatment in different of life domains, such as contacts with neighbours or with the police. To examine the domain-specific organisation of minority and majority perceptions of personal discrimination (Hypothesis 1 on domain specificity), we tested the measurement equivalence of perceived discrimination in different domains across Turkish and Moroccan minorities and majority Belgians.

\section{Intersectionality and locality}

The third and last research aim was to differentiate further between varying levels of perceived discrimination within the ethnic groups. Recently, there is more attention for intersectionality so that, for instance, ethnic discrimination may play our differently along gender and class lines within ethnic groups. Findings on the intersection of ethnicity with gender are mixed. For instance, Levin et al. (2002) found no gender differences for Latin and African American minorities. Depending on the intergroup context, other studies yield variable associations between gender and perceived ethnic discrimination (e.g., Barry and Grilo, 2003). In the case of Muslim minorities, Muslim men tend to be more negatively stereotyped than women (Voas and Fleischmann, 2012), and may hence experience more discrimination. Yet, also Muslim women may experience gendered forms of ethnic discrimination in specific domains or situations, for instance when wearing a headscarf while taking an exam or applying for a job (Hypothesis 2 on gender).

With regard to the intersection of ethnicity with unequal socio-economic attainments, such as education and employment, findings differ between majority and minority groups. Majority perceptions of discrimination are reliably predicted by lower levels of education, in line with more perceived ethnic threat and competition among less educated majority 
members (Meuleman, 2011). On the minority side, associations with socio-economic attainment levels are less straightforward, however. Higher education does not seem to protect minority citizens from experiencing discrimination; and some recent findings suggest even higher levels of perceived discrimination among more highly educated Muslims (Dixon et al. 2010, Tolsma, Lubbers and Gijsberts, 2012; Doorn, Scheepers and Dagevos, 2012). Accordingly, Portes, Parker and Cobas (1980) argued that ethnic competition would become salient for ethnic minorities, as they attain higher socio-economic status and become more aware of discriminatory processes. To conclude, we expect that economically more vulnerable majority members will perceive more discrimination. On the minority side, however, perceived discrimination may be decoupled from socio-economic attainment ( attainment).

Looking beyond socio-demographic characteristics such as gender and socio-economic attainment, we also include local intergroup climates as proximal contextual predictors of perceived discrimination. In view of a generally hostile public opinion climate against Muslim minorities in European societies, we explored how perceived discrimination relates to local media consumption. Local media use indirectly measures exposure to prevailing negative images of Muslim minorities in public opinion and in political discourse (Van Dijk, 1991; Van Acker, 2012). For minorities, negative media images of Muslims may encourage the framing of personal experiences of negative contact with majority citizens as perceived discrimination at the intergroup level. For majority citizens, media images may or may not add to their feelings of threat in a predominantly negative opinion climate. To the extent that local media portray intergroup relations in a negative way, we expect that more local media consumption will predict more perceived discrimination among the second-generation (Hypothesis 4 on local media use). 
In addition, we examine appraisals of the local intergroup context and climate as a more direct test of the theoretical association of perceived discrimination with the quality of local intergroup relations in the city. First, perceived group size, or higher shares of one's in-group in the neighbourhood may buffer feelings of group threat (Quillian, 1995), and hence reduce perceived discrimination. For majorities, their small or decreasing relative in-group size in relation to local minorities may elicit feelings of group threat as ever larger numbers of minorities may tip the local power balance to their disadvantage. For minorities, in contrast, their relative in-group size in the neighborhood may shield them from experiencing discrimination to the extent that their numbers would reduce opportunities for discrimination and increase their local power or control.

Second, both minority and majority participants rated perceived economic and safety threat to their local living conditions. From a majority group perspective in particular, the expectation that living conditions will deteriorate in the future might trigger feelings of group threat, when local decline is attributed to the increasing presence of minorities, thus fuelling majority perceptions of reverse discrimination (Wimmer, 2000). Third, perceived hostility in local intergroup relations is a powerful amplifier of negative personal experiences of failed intergroup contact for both minority and majority citizens, because they define such experiences as a collective and illegitimate group condition. In brief, we hypothesize that smaller perceived in-group size and more perceived threat and hostility in local intergroup relations would exacerbate mutual perceptions of discrimination (Hypothesis 5 on local climates).

\section{THE CASE OF ANTWERP}

We focus on the case of Antwerp, the biggest monolingual city in Flanders and the second biggest city of Belgium which has received a relatively large share of Turkish and Moroccan 
immigrants since the early 1970s. Table 2 shows the numbers of the Moroccan and Turkish origin groups in Antwerp. Together, they make up 10\% of the total population. Nevertheless, the official statistics on the basis of nationality hugely under-represent the second generation which is here defined by the criterion of having at least one parent with a foreign place of birth. As a world port, Antwerp has developed an industrial economy and attracted many lowskilled workers, who were hit hard by a late yet brutal post-industrial transition. As labour migrants, Turkish and Moroccan workers in Antwerp were originally recruited from the less developed regions of Turkey and Morocco with generally very low levels of literacy and schooling. As a consequence, they were disproportionately affected by the shrinking of the industrial sector, which resulted in high rates of unemployment and economic inactivity among the first generation.

[Table 2 about here]

Apart from its economic make-up and its difficult transition to a post-industrial labour market, there is another reason why Antwerp is a critical case for the study of discrimination: its highly salient, polarised and politicised 'ethnic divides' separating majority and minority communities. Ethnic divisions are due - at least in part- to the electoral success of the antiimmigrant party Vlaams Belang (Hino, 2007; Swyngedouw and Van Craen, 2001/2). Over the last decade, the large and steadily increasing electorate of the party (i.e., $35 \%$ of the votes in Antwerp as against 25\% in Flanders at large in the last regional elections in 2004) has dominated public policies and debates over issues of immigration and integration in line with the rise of extreme-right in other parts of Europe. While the discourse of the Vlaams Belang excludes ethnic minorities, it offers a frame to the majority group that blames ethnic minorities for social problems. Furthermore, local media coverage of Vlaams Belang, offensive party slogans and posters depicting Muslims as a threat (such as pictures of minarets 
rising above the cathedral) as well as the party's call for a forced repatriation of immigrants have raised awareness of discrimination among Muslim citizens in particular. Structurally unequal and highly politicised intergroup divides make Antwerp an interesting case for studying perceived discrimination.

\section{DATA AND MEASURES}

The present study makes use of the Belgian TIES surveys 2007-2008 among random samples of the Turkish $(\mathrm{N}=358)$ and Moroccan second generation $(\mathrm{N}=312)$ and a majority Belgian comparison sample $(\mathrm{N}=303)$ from the same urban areas in Antwerp (Swyngedouw, Phalet, Baysu, Vandezande and Fleischmann, 2008). Trained interviewers conducted Computer Assisted Personal Interviews (CAPI) at respondents' homes. The overall response was 58\% in Antwerp; see Appendix 2 for group-specific response rates. Second-generation participants were residents of the City of Antwerp between the ages of 18 and 35 who were born in Belgium with at least one parent who was born in Turkey or Morocco. Majority Belgian participants (i.e., Belgian-born from two Belgian-born parents) were selected in the same age range and urban areas as the second generation to increase the probability of intergroup contact and the comparability of their local living conditions.

Perceived personal discrimination is defined as 'unfair or hostile treatment because of one's background or origin' and measured with seven items, which are rated on a five-point scale from 'never' to 'frequently'. Participants were asked, for example: “As a secondary school student, how often did you personally experience hostility or unfair treatment because of your origin or background?". Similar questions were asked in other life domains, including looking for a job, or at work, on the street or in public transports, in the neighborhood, when going out in dancing's, cafés, or restaurants, and in encounters with the police. 
Gender was a dummy (women, man). Socio-economic attainment was measured as (1) employment status (unemployed, employed, student, inactive: other) and (2) educational qualifications (attending or having completed higher education, less than higher education). Local media consumption was measured with the question "Do you follow the news about Antwerp local politics from newspapers, television, radio, or Internet?" with answers ranging from 'never' to 'frequently' on a five-point scale.

As indicators of perceived local climates, we included measures of (1) relative in-group size ("If you now think of all the people living in your neighborhood, how many of them are of [Turkish/ Moroccan/Belgian] origin?" from almost none, over less than 25\%, approximately $25 \%$, approximately half, approximately $75 \%$, more than $75 \%$, to almost everybody on a seven-point scale), (2) perceived economic threat ("I am afraid that my living conditions, such as my income and work, will become worse in the near future") and (3) perceived safety threat ("violence and vandalism will increase in our society" from totally disagree to totally agree on a five-pointscale); and lastly, (4) evaluations of intergroup hostility ("How would you describe the relationship between people of Belgian origin and people of [Turkish/Moroccan] origin in Antwerp?" from not friendly at all to very friendly on a five-point scale).

\section{RESULTS AND DISCUSSION}

\section{Descriptive Findings}

Figures 1 and 2 show descriptive findings on the average levels of perceived personal discrimination (PD) across gender, groups and life domains. In line with a well-documented ethnic hierarchy in Belgium, the Moroccan minority perceived most discrimination, the Turkish minority less, and majority Belgians least. Minority and majority groups also differ in the perceived grounds of discriminatory treatment (igures 3-5 in Appendix 3). Across 
groups, ethnic origin was the most important ground (resp. 45\%, 37\% and 33\% of Moroccan, Turkish and Belgian reports). Minorities also mentioned skin colour (resp. 28\% and 25\% of Moroccan and Turkish reports) and religion (resp. 13\% and 18\%) with some frequency, in line with bright ethno-religious group boundaries. Majorities from their side also mentioned social class (16\%) and 'other reasons' (32\%). While perceived discrimination is mainly structured along ethnic lines, it has different meanings for Muslim minorities, who foreground religion as well as race, and for the majority, who indicate social class or other social grounds which our questionnaire does not fully capture.

Furthermore, perceived discrimination is gendered, with men reporting more personal discrimination than women, in particular Moroccan men. In addition, discrimination is gendered in terms of the situations that give rise to discriminatory encounters. For instance, minority women reported most discrimination on the street and in public transport, while minority men perceived most discrimination when going out, especially Moroccan Muslims. The share of Moroccan-origin men who reported some discrimination ranges between $45 \%$ and $70 \%$ across domains. Clearly, Moroccan second generation men see themselves as prime targets of discrimination.

[Figure $1 \& 2$ about here]

To sum up, descriptive findings show considerable variation between and within ethnic groups across gender and across different life domains. In the following sections, we make use of structural equation modelling to formally test these differences.

\section{Socio-economic and Civic Life Domains}

Our second research aim was to examine variation between different domains of perceived personal discrimination. In order to reduce measurement error and to test the cross-group 
equivalence or comparability of our domain-specific measures, we specified latent factor models using Mplus software (version 6.0, Muthén and Muthén, 2010). Our manifest 'indicator' variables are listed in Appendix 1: PD at school, PD on the street or in public transport, PD in the neighbourhood, PD when going out, PD in encounters with the police, PD at the workplace and PD when looking for a job.

First, we tested the (competing) hypothesis that the seven indicators would form one common factor capturing a generalised perception of discrimination across life domains. This most simple model allows that levels of perceived discrimination in different domains vary, as long as they 'vary together'. The one-factor model did not fit the data, however, in any of the groups under study. We used conventional informal fit indices to evaluate global model fit with cut-offs of CFI $\geq 0.90$ and RMSEA $<0.06$ for acceptable or good models (Hu and Bentler, 1999). Apart from a bad global model fit, several parameter estimates in each groups yielded high and problematic modification indices. In accordance with $\underline{\text { Hypothesis } 1}$ on domain-specificity, the one-factor model of perceived discrimination had to be rejected. Next, we specified separate multiple-group confirmatory factor models for socioeconomic and civic domains. The socio-economic domains (at workplace, looking for a job, and at school) were highly correlated among themselves and distinct from other domains (except for significant correlations of PD at school and in civic domains). Another reason to model socio-economic and civic domains separately is that we wanted to include all participants in our model of the civic domains, also those who had not looked for a job or worked, and hence did not answer socio-economic discrimination questions. Figure 6 shows the common unstandardized factor models across groups for socio-economic and civic life domains.

[Figure 6 about here] 
We achieved full measurement invariance across minority and majority comparison groups in the socio-economic domain. The three indicators, PD while looking for a job, in the workplace and in school (See Model 2 in Figure 6) formed one latent factor. The fully ivariant one-factor solution across groups showed a good model fit. Compared to majority Belgians, both minorities reported significantly higher latent mean levels of perceived discrimination in the socio-economic domain.

We found the same latent structure of perceived discrimination in civic domains across minority and majority comparison groups (see Model 1 in Figure 6), which achieved full measurement equivalence (equal loadings and thresholds across groups). The four indicators formed two factors: one factor consisted of PD on the street or in public transport and in the neighbourhood and grouped perceptions of discrimination in public space; another factor combined PD when going out and in contacts with the police and referred to the coercive use of authority in the context of screenings by night club bouncers and identity checks by the police. This model confirmed significant group differences in latent mean levels of discrimination in civic domains, so that minorities perceived more discrimination than the majority in public space; and Moroccans perceived most discrimination in conflicts with authority.

We achieved full measurement invariance across minority and majority comparison groups in socio-economic domains. The three indicators, PD while looking for a job, in the workplace, and at school (see Model 2 in Figure 6) formed one latent factor grouping perceptions of discrimination in education and in the labour market. The fully invariant onefactor solution across groups showed a good model fit. Compared to majority Belgians, both minorities reported significantly higher latent mean levels of perceived discrimination in the socio-economic domain. 


\section{Internal Differentiation}

Our third research aim was to differentiate perceptions of personal discrimination within the groups: who perceives more discrimination? Because we could establish full measurement invariance, we may add predictors to the models of perceived discrimination in both civic and socio-economic domains. All parameter estimates refer to unique effects that are controlled for all the other variables in the model. Standardised within group coefficients for all effects can be found in Tables 3 and 4.

In line with Hypothesis 2 , gender was a strong predictor of perceived discrimination in both socio-economic and civic domains. Minority men were more likely to perceive discrimination than women across domains, yet the strongest association with gender was found for conflict with authority. Discriminatory experiences when going out and with the police are primarily a male problem, particularly for Moroccan men. Also majority Belgian men perceived more discrimination than women, but only in civic domains.

$\underline{\text { Hypothesis } 3}$ on socio-economic attainment was confirmed in part. For majority Belgians, both higher education and employment predicted less perceived discrimination (although majority students reported significantly more discrimination in public spaces, see

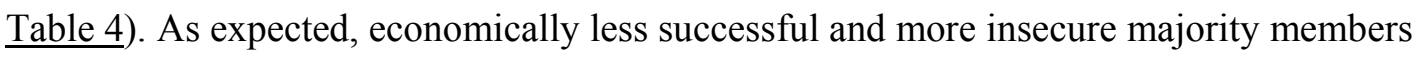
were more susceptible to feelings of threat or competition in intergroup relations with Muslim minorities, which underlie majority perceptions of reverse discrimination. For minorities, perceived discrimination was largely decoupled from socio-economic attainment, however (see Table 3). While higher education was dissociated from perceived discrimination among the second generation, more highly educated Turkish women perceived more discriminatory treatment in socio-economic domains. Similarly, student status was unrelated to perceived discrimination for the Turkish second generation; and it was related in opposite directions to 


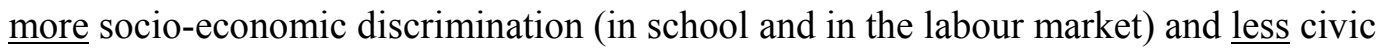
discrimination (when going out and by police) among the Moroccan second generation. Female minority students, however, in particular Moroccan women, were more likely to perceive personal discrimination in civic domains. Gendered associations of perceived discrimination with higher education may reflect (at least in part) the headscarf issue in Belgian schools and cities. More generally, our findings for minority women only, not for men, are in line with an expected increase in the exposure to, and awareness of, discrimination among successful members of the second generation (Portes et al., 1980).

Turning to the labour market, we find that unemployment predicted more perceived discrimination in the economic domain for the Turkish second generation, as it did for majority Belgians. Yet, employment did not protect the Moroccan second generation from discrimination. To the contrary, Moroccans who were unemployed perceived rather less discrimination in civic domains. So did economically inactive Turks. Plausibly, youngsters who did not participate in the labour market lived more segregated lives and were hence less exposed to intergroup contact with majority Belgians, be it positive or negative.

Looking beyond socio-economic attainment, we also tested the role of local media and intergroup climates (see Tables 3 and 4 ). In line with $\underline{\text { Hypothesis } 4}$ on local media consumption, more media exposure predicted more perceived discrimination among the Turkish second generation. Since local media in Antwerp would portray Muslim minorities as posing a threat to the standard of living and way of life of the majority population, this finding suggests that negative media images can amplify intergroup tensions and perceptions of discrimination (Van Acker, 2012; Van Dijk, 1991). There were no significant effects of media use on Moroccan and majority Belgian perceptions of discrimination. Possibly, Moroccans had more first-hand experience of discrimination than Turks, and were hence less affected by negative media messages about their group. As majority Belgian participants in the survey 
would live in the same ethnically mixed areas as the second generation, they too may rely less on mass media and more on shared negative experiences of local intergroup relations.

[Table 3 and 4 about here]

Turning to minority and majority appraisals of local intergroup climates, we find partial support for Hypothesis 5 relating mutual perceptions of discrimination to local intergroup tension (see Tables 3 and 4). Firstly, relative group size (i.e., perceived in-group presence in one's neighbourhood) predicted perceived discrimination in different ways for minorities and majority inhabitants. Thus, majority Belgians were less likely to perceive reverse discrimination in neighbourhoods where the majority was seen to be more numerous. In line with expectations from intergroup threat, majority inhabitants perceived more reverse discrimination in 'majority minority' neighbourhoods, where they would be less able to avoid intergroup contact and where the local power balance would shift to the advantage of minorities. For second-generation Turks, relative in-group size was unrelated to perceived discrimination. For Moroccans, the association between relative in-group size and perceived discrimination was reversed, so that higher proportions of Moroccan neighbours predicted

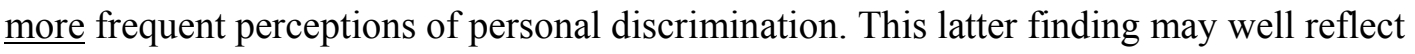
increased threat and hostility in local intergroup settings with a stronger presence of most devalued Moroccan Muslims.

Along those lines, perceived safety and socio-economic threats, or the fear of increasing violence and declining living conditions, were significant predictors of perceived discrimination for both minority groups. Thus, second-generation Muslims who were more worried about their future living standards or about violence in their immediate environment, perceived more personal discrimination. This finding suggests that minority perceptions of 
discrimination may be part and parcel of recursive cycles of 'ethnic threat' (Wimmer, 2000), when perceived discrimination reflects local intergroup tensions and related concerns about the future of the second generation. Threat effects were not significant for majority Belgians.

Finally, strong associations of minority perceptions of personal discrimination with perceived intergroup hostility provide most direct support for $\underline{\text { Hypothesis } 5}$ on local intergroup climates. Across both minorities, second-generation Muslims reported more personal discrimination when they saw local intergroup relations as more hostile. We argued that negative appraisals of intergroup relations with the local majority would increase the likelihood of framing negative interpersonal encounters as discriminatory treatment at the intergroup level. Perceived hostility was unrelated to majority perceptions of reverse discrimination.

\section{CONCLUSION}

Drawing on large-scale TIES surveys of second-generation Muslims and majority Belgians in the multicultural city of Antwerp-Belgium as a deeply divided local intergroup context, our research examined both minority and majority perspectives on experiences of (reverse) discrimination in different life domains. While there is solid evidence of actual discrimination against Muslim minorities in Antwerp, as in other European cities and societies (Voas and Fleischmann, 2012), our research focus was on perceptions of personal discrimination as an influential yet often ill-understood social and political experience in their own right.

Reasoning from intergroup relations, we situate perceived discrimination in local intergroup relations between Muslim minorities and local majorities. We argued that feelings of intergroup threat or competition between Muslim minorities and local majorities may give rise to (mutual) perceptions of (reverse) discrimination in intergroup encounters. Thus, minority experiences of discrimination in encounters with fellow citizens, employers or police 
officers would reflect their subordinate group position as devalued minority members, which implies increased exposure to, or restricted protection from, discriminatory treatment or impact in their daily interactions. Importantly, the second generation is increasingly internally diverse with significant portions accessing higher education and competing for highly qualified jobs. We argued that also successful second-generation Muslims may experience discrimination at least in some domains of life. In addition, we argued that perceptions of discrimination are not restricted to minorities. In today's multicultural cities, also members of the nominal majority may experience so-called reverse discrimination, for instance when they are outnumbered in 'majority minority' neighborhoods or when they are competing with minorities for the better segments of local job or housing markets. To shed light on the intergroup dynamics that inform perceptions of discrimination, our comparative study includes much less researched majority perceptions along with minority perceptions of discrimination. Moreover, it extends the scope of (quantitative) discrimination measures beyond most researched socio-economic domains into other domains of life, such as intergroup encounters with majority neighbours or with the police.

Our study had a threefold aim: (1) to describe minority and majority group perspectives on discrimination in negative intergroup encounters; (2) to situate perceptions of discrimination in different life domains, including socio-economic as well as civic domains of life; and (3) to differentiate internally within ethnic groups between gender, unequal attainments, and local intergroup climates. Specifically, we examined intersections with gender and unequal attainments, as well as associations of perceived discrimination with local media consumption (as proxy for exposure to a negative public opinion climate) and with minority and majority appraisals of local intergroup relations. We derived our hypotheses from an intergroup relations approach of ethnic competition and threat on both sides of the ethno-religious divide between Muslim minorities and majority Belgians in Antwerp. 
In a nutshell, our descriptive findings show firstly, that average levels of perceived discrimination reflect unequal group positions in a quasi-consensual ethnic hierarchy with Moroccan minorities at the bottom and the Belgian majority at the top. In addition to most salient ethnic grounds across groups, both religion and race are more salient as grounds for personally experienced discrimination in the eyes of minority groups than in those of the majority. Interestingly, one in three majority perceptions of discrimination are attributed to (White) ethnic grounds. While perceived discrimination is to some degree reciprocal in negative intergroup contact between Muslim minorities and majority Belgians, for instance in diverse urban neighborhoods, minority perceptions suggest most frequent, most exclusively ethnically grounded, and most pervasive experiences of discrimination across intergroup situations or domains.

Secondly, when we examine how perceived discrimination is organized around different life domains, and in line with Hypothesis 1 on domain-specificity, multi-group confirmatory factor analysis distinguishes between broad and comparable socio-economic (in school, at work, and looking for a job) and civic domains (public transport or street, police and going out) as distinct types of intergroup contexts where people may experience discriminatory encounters. Within the civic domain, discriminatory contact with fellow citizens in public spaces such as one's neighborhood or street could be further discerned from a specific factor for police controls and going out. Interestingly, both subdomains in the broad civic domain are gendered, with men perceiving more discrimination in encounters with the police or in night outings, and women in their daily contacts with neighbors and strangers in public spaces (e.g., one's street, neighborhood or public transport).

Lastly, Hypotheses 2 to 5 propose the internal differentiation of perceived discrimination within each minority group. In a nutshell, the findings highlight considerable internal variation in perceptions of discrimination as a function of gender, socio-economic 
attainments, and local intergroup climates. First, there were clear gender differences in perceived discrimination, with more personal discrimination overall on the male side across minority and majority groups. Our findings highlight the importance of taking into account the intersection of ethnicity with gender in research on perceived discrimination. Second, associations with socio-economic attainment (educational and labor market participation) confirm Hypothesis 5 which expects more perceived personal discrimination among less highly educated and unemployed majority Belgians, in line with selective ethnic competition and threat. On the minority side, perceived discrimination was largely decoupled from socioeconomic attainments. As expected by Hypothesis 3, higher socio-economic attainment does not consistently protect Muslim youngsters from experiencing discrimination. This decoupled pattern is qualified, however, by some group- and gender-specific attainment effects. Thus, education and student status do seem to entail more perceived discrimination among Muslim women, possible due in part to headscarf issues in Belgian schools. Interestingly, unemployment has somewhat opposite effects on the Turkish and Moroccan secondgeneration, leading to more discrimination in the economic realm for Turks, and lowering discrimination in the civic realm (especially by police) for Moroccans.

Next, we turn to more direct tests of the role of local intergroup climates in shaping perceptions of discrimination. In line with Hypothesis 4 on local media consumption as a proxy for minority exposure to prevailing negative stereotypes of Muslims and Islam, we find that the Turkish second generation perceive more discrimination when they are more attuned to the local news in the city. In contrast, Moroccan Belgians report more first-hand experiences of discrimination as a most stigmatized group regardless of media exposure. Media consumption does not predict majority perceptions of discrimination either. Finally, we asked participants to estimate their relative group size in their neighborhood and to rate feelings of economic threat and safety threat, as well as their appraisal of intergroup hostility 
in the city. Overall, significant associations were in the expected direction (cf. Hypothesis 5); and they provide most direct support for an intergroup relations approach to perceived discrimination. Both minority and majority citizens were affected by the local intergroup climate feelings, so that perceived personal discrimination and perceived ethnic threat and hostility are closely entwined in local intergroup contexts.

While the cross-sectional data and analyses do not carry causal interpretations, our comparative findings establish the validity of our domain-specific or multi-dimensional conception and measurement of perceived personal discrimination. Moreover, the findings highlight different group perspectives on unequal and often hostile intergroup relations between Muslim minority and majority citizens and communities in a European multicultural city. While discrimination perceptions may be more pronounced in the highly divisive socioeconomic and socio-political context of Antwerp than in some other European cities, the varying perceptions between and within minority and majority groups also have generic added value. Our findings show the multi-faceted nature of perceived discrimination by explicating the different group perspectives and the intersections of ethnicity with gender, attainment, media exposure and local climate. They call for the contextualization of discriminatory encounters as embedded within unequal and often conflicting ethnic relations in multicultural cities as local intergroup contexts.

Future research may examine the quantity and quality of encounters (contact) between these groups in different life domains and its association with perceived personal discrimination. Lastly, our conclusions are based on a case study. The predictors of perceived personal discrimination as well as the perspectives of majority and minority groups are partly determined by the local and intergroup contexts. Antwerp presents a special case where the immigration debate is politicized and anti-immigrant sentiment is strong; as such, we suggest, it presents a good starting point for multi-city comparative studies of perceived personal 
discrimination. Building on this case study, comparative study of Antwerp and other multicultural cities can provide more insight into what is a more consistent about discrimination experiences of children of immigrants and how the predictors of it vary across cities with different local and intergroup contexts. 


\section{REFERENCES}

Alba, R. D. 2005 "Bright vs. Blurred boundaries: Second generation assimilation and exclusion in France, Germany and the United States." Ethnic and Racial Studies 28(1):20-49.

Amadieu, J. 2004 Enquête “testing” sur CV, Adia/Paris I-Observatoire des Discriminations.

Barry T. D., and C. Grilo 2003 “Cultural, Self-esteem and demographic correlates of perception of personal and group discrimination among East Asian immigrants." American Journal of Orthopsychiatry 73(2):223-229.

Blank, R., M. Dabady and C. Citro 2004 Measuring racial discrimination. Washington D.C.: The National Academies Press.

Blumer, H. 1958 "Race prejudice as a sense of group position." Pacific Sociological Review $1: 3-7$.

Bobo, L. 1988 "Group conflict, prejudice, and the paradox of contemporary racial attitudes" In Eliminating Racism: Profiles In Controversy. Ed. Katz, P.A. and D.A. Taylor, New York: Plenum.

Castelain-Kinet, F., L. Es-Safi , S. Feld and F. Lannoy 1998 "Results in the Walloon region." In "Discrimination in access to employment on grounds of foreign origin: the case of Belgium.” International Migration Papers 23. Geneva, ILO

Coser, L. A. Ed. 1956 The functions of social conflict. (Vol. 9). Routledge.

De Rycke, K, Swyngedouw, M. and Phalet, K. 1999. "De subjectieve ervaring van discriminatie.” In Minderheden in Brussel. Ed. Swyngedouw, M., Phalet, K. and Deschouwer, K. Brussel: VUB Press.

Dixon J., K. Durrheim, C. Tredoux, L. Tropp, C. Beverly and L. Eaton 2010 "A Paradox of Integration? Interracial contact, Prejudice reduction, and perceptions of Racial discrimination.” Journal of Social Issues 66(2):401-406.

Doorn M., P. Scheepers, and J. Dagevos 2012 "Explaining the Integration Paradox Among Small Immigrant Groups in the Netherlands." International Migration and Integration 1-20.

Feagin, J. 1991 "The Continuing Significance of Race: Anti-black Discrimination in Public Places" American Sociological Review 56(1):101-116.

Fleischmann, F., K. Phalet, and M. Swyngedouw 2013 "Dual identity under threat: When and how do Turkish and Moroccan minorities engage in politics?" Zeitschrift für Psychologie 221(4):214.

FRA 2007 "Report on Racism and Xenophobia in the Member States of the EU.", TK-AK07-002-EN-C.

Hagendoorn, L. 1995 "Intergroup biases in multiple group systems: The perception of ethnic hierarchies." European Review of Social Psychology 6(1):199-228. 
Heath, A. and Y. Li 2007 Measuring the size of the employer contribution to the ethnic minority employment gap, paper for the national employment panel.

Heath, A. F., C. Rothon, and E. Kilpi. 2008 "The second generation in Western Europe: Education, unemployment, and occupational attainment." Annual Review of Sociology 34:211-235.

Hebl Michelle R., J. B. Foster, L.M. Mannix, J. F. Dovidio 2009 "Formal and Interpersonal Discrimination: A Field Study of Bias Toward Homosexual Applicants." Personality and Social Psychology Bulletin, 28(6), 815-825.

Hino, A. 2007 “Kenmerken van stemgedrag op 'nieuwe partijen'. Agalev en Vlaams Blok". In De kiezer onderzocht. De verkiezingen van 2003 en 2004 in Vlaanderen. Ed. Swyngedouw, M., J. Billiet and B. Goeminne Leuven: Universitaire Press, Leuven.

Holzer, H. and J. Ludwig 2003 "Measuring discrimination in education: Are methodologies from labor and markets useful?" Teachers College Record 105(6):1147-1178.

Hu, L. and P. Bentler 1999 "Cut-off criteria for fit indexes in covariance structure analysis: Conventional criteria versus new alternatives.” Structural Equation Modelling 6(1):1-55.

LeVine, R. A., and D.T. Campbell 1972 Ethnocentrism: Theories of conflict, ethnic attitudes, and group behavior. Oxford, England: John Wiley \& Sons.

Levin, S., S. Sinclair, R. C. Veneigas, and P. Taylor 2002 "Perceived discrimination in the context of multiple group memberships.” Psychological Science 13(6):557-560.

Martens, A., N. Ouali, M. Van de maele, S. Vertommen, P. Dryon and H. Verhoeven 2005 Etnische discriminatie op de arbeidsmarkt in het Brussels Hoofdstedelijk Gewest. Brussel: Brussels observatorium van de arbeidsmarkt en kwalificaties.

Maxwell, R. 2014 "Perceived discrimination across institutional fields: Racial minorities in the United Kingdom.” European Sociological Review doi:10.1093/esr/jcu094

Meuleman B. 2011 "Perceived economic threat and anti-immigration attitudes: Effects of immigrant group size and economic conditions revisited." In Cross-cultural Analysis Methods and Applications. Eds. E. Davidov, P. Schmidt and J. Billet, London: Rountledge. Pp. 281319.

Muthén, B. 1984 “A general structural equation model with dichotomous, ordered categorical, and continuous latent variable indicators." Psychometrika 49:115-132.

Muthén, L.K. and B.O.Muthén 2010. Mplus User's Guide

Neels, K. and R. Stoop 2000. "Reassessing the Ethnic Gap. Employment of Younger Turks and Moroccans in Belgium" In Communities and Generations: Turkish and Moroccan Populations in Belgium, Ed. R. Lesthaeghe, Brussel, Vrije Universiteit Brussel, Pp. 279-320.

Kluegel, J., and L. Bobo. 2001 "Perceived group discrimination and policy attitudes: The sources and consequences of the race and gender gaps." In Urban Inequality: Evidence from 
Four Cities Eds. A. O'Connor, C. Tilly, and L. D. Bobo, New York: Russell Sage Foundation, Pp. 163-216.

Pascoe, E. A., and L. S. Richman 2009 Perceived discrimination and health: a meta-analytic review. Psychological bulletin, 135(4), 531.

Phalet, K., C. van Lotringen and H. Entzinger 2000 Islam in de multiculturele samenleving: Opvattingen van jongeren in Rotterdam. Commissioned by ERCOMER Reports, Utrecht.

Phalet, K., and M. Gijsberts 2007 "When ways of life collide: A minority perspective" In Culture and conflict: Liber Amicorum for Louk Hagendoorn. Eds. E. Poppe and M. Verkuyten Amsterdam, Netherlands: Aksant. Pp.141-154.

Phalet, K. and A. Heath. 2010 "From ethnic boundaries to ethnic penalties: Urban economies and the Turkish second generation." American Behavioral Scientist 53(12):1824-1850.

Phalet, K., and A. Heath 2011 "Ethnic community, urban economy and second-generation attainment: Turkish disadvantage in Belgium." In Dimensions of Diversity: The Children of Immigrants in North America and Western Europe. Eds. R. Alba and M. N. Waters, New York: New York University Press, 135-165.

Portes, Alejandro, and Rubén G. Rumbaut. 2001 Legacies: The story of the immigrant second generation. University of California Press.

Portes, A., Parker, R. N., and Cobas J. A. 1980 "Assimilation or Consciousness: perceptions of the US society among recent Latin American immigrants to the United States." Social Forces, 59(1):220-224.

Quillian, L. 1995 "Prejudice as a response to perceived group threat: population composition and anti-immigrant and racial prejudice in Europe." American Sociological Review 69(4):586611.

Reitz, J. and R. Bannerjee 2007 "Racial inequality, social cohesion, and policy issues in Canada." In Belonging, Diversity, Recognition and Shared Citizenship in Canada Eds. K. Banting, T.J. Courchene and L. Seidle. Montreal: Institute for Research on Public Policy. Pp. 489-545.

Rink, N., K. Phalet, and M. Swyngedouw 2008 "The effects of immigrant population size, unemployment, and individual characteristics on voting for the Vlaams Blok in Flanders 1991-1999.” European Sociological Review 25(4):411-424.

Russell, H., E. Quinn, K. O. Riain, and F. McGinnity 2009 Experience of Discrimination in Ireland: Analysis of the QNHS Equality Module. Economic and Social Research Institute (ESRI), number BKMNEXT120.

Rustenbach, E. 2010 "Sources of Negative Attitudes Toward Immigrants in Europe: A Multi-Level Analysis.” International Migration Review 44(1):53-77. 
Scheepers, P., M. Gijsberts and M. Coenders 2002 "Ethnic exclusionism in European countries, public opposition to civil rights for legal migrants as a response to perceived ethnic threat.” European Sociological Review 18(1):17-34.

Silberman, R., Alba, R. and Fournier, I. 2007 "Segmented assimilation in France? Discrimination in the labour market against the second generation." Ethnic and racial studies, 30(1):1-27.

Simon, P. 2005 "The measurement of racial discrimination: the policy use of statistics." International Social Science Journal 57(183):9-25.

Steele, C. M. 2010 Whistling Vivaldi: And Other Clues To How Stereotypes Affect Us (Issues Of Our Time) New York: W. W. Norton and Company.

Swim, Janet K., K. Johnston, N. B. Pearson 2009 "Daily Experiences With Heterosexism: Relations Between Heterosexist Hassles and Psychological Well-Being" Journal of Social and Clinical Psychology, 28(5):597-629.

Swyngedouw, M, K. Phalet and K. Deschouwer 1999 Minderheden in Brussel. Brussel: VUB Press.

Swyngedouw, M. and M. Van Craen 2001/2 "Vlaams Blok en de natiestaat. Het rechtsradicale Vlaams-nationalisme onder de loep" Fédéralisme Régionalisme Volume 2: 20012002 - Extrême droite et fédéralisme.

Swyngedouw, M., K. Phalet, G. Baysu, V. Vandezande, and F. Fleischmann 2008 Trajectories and experiences of Turkish, Moroccan and native Belgians in Antwerp and Brussels: Codebook and Technical Report of the TIES Surveys 2007-2008 Belgium. Leuven: ISPO and CSCP, University of Leuven.

Ten Teije, I., M. Coenders and M. Verkuyten 2012. "The Paradox of Integration.” Social Psychology 1-11.

Tolsma, J., M. Lubbers and M. Gijsberts 2012 "Education and cultural integration among ethnic minorities and natives in the Netherlands: A test of the integration paradox." Journal of Ethnic and Migration Studies 38(5):793-813.

Van Acker, K. 2012 Flander's real and present threat: How representations of intergroup relations shape attitudes towards Muslim minorities. PhD. Dissertation.

Van Acker, K., and N. Vanbeselaere 2011. "Bringing together acculturation theory and intergroup contact theory: Predictors of Flemings' expectations of Turks' acculturation behavior." International Journal of Intercultural Relations 35(3): 334-345.

Vandezande, V., K. Phalet and M. Swyngedouw 2011 "Do feelings of discrimination explain the riots in Brussels? A comparison of Moroccan and Turkish groups in Brussels and Antwerp.” Brussels Studies 47:1-14.

Van Dijk, T. A., and T. A. Van Dijk 1991 Racism and the Press. London: Routledge. 
Van Dijk, T. A. 2000 "Ideologies, racism, discourse: Debates on immigration and ethnic issues." In Comparative Perspectives on Racism, Eds. J. Wal and M. Verkuyten. Aldershot etc. Ashgate. Pp. 91-116.

Voas, D., and F. Fleischmann. 2012 "Islam moves west: Religious change in the first and second generations." Annual Review of Sociology 38:525-545.

Wimmer, A. 2000 "Racism in nationalised states: A framework for comparative research". In Comparative perspectives on racism. Ed. Ter Wal, J. and M. Verkuyten, Alderschot: Ashgate.

Yinger, J. 1998 "Evidence on discrimination in consumer markets" The Journal of Economic Perspectives 12(2):23-40.

Zegers de Beijl, R. Ed. 2000 Documenting discrimination against migrant workers in the labour market: A comparative study of four European countries. Geneva: International Labour Organisation.

CGKR 2012 "Naar alternatieve maatregelen in de strijd tegen discriminatie en haatmisdrijven" Accessed October, 30. http://www.diversiteit.be/naar-alternatievemaatregelen-de-strijd-tegen-discriminatie-en-haatmisdrijven 


\section{TABLES \& FIGURES}

Table 1. Evaluations of Belgian, Turkish and Moroccan Groups by Majority Belgian, Turkish and Moroccan participants (mean ratings from $0=$ most negative to $100=$ most positive feelings)

\begin{tabular}{ccccc}
\hline Belgians & Turks & Moroccans & $\begin{array}{c}\text { Intergroup } \\
\text { Evaluations }^{\dagger}\end{array}$ \\
\hline Evaluations of & & & & \\
Belgians & 79 (in-group) & 73 & 70 & 72 \\
Turks & 62 & 79 (in-group) & 63 & 63 \\
Moroccans & 55 & 51 & 74 (in-group) & 53 \\
\hline
\end{tabular}

$\dagger$ mean of the two out-group evaluations

Source: TIES BELGIUM 2007-2008, ISPO-CSCP, University of Leuven

Table 2. Turkish and Moroccan Origin Populations and Belgian Reference Population in Antwerp (2007)

\begin{tabular}{rcccc}
\hline & \multicolumn{2}{c}{ Current nationality } & \multicolumn{2}{c}{ National origin of parents } \\
& $\mathrm{N}$ & $\%$ & $\mathrm{~N}$ & $\%$ \\
\hline Belgian origin & 40,2470 & $86.4 \%$ & 342,116 & $73.5 \%$ \\
Moroccan origin & 11,797 & $2.5 \%$ & 34,751 & $7.5 \%$ \\
Turkish origin & 4,242 & $0.09 \%$ & 11,215 & $2.4 \%$ \\
\hline TOTAL & 465,596 & $100 \%$ & 465,596 & $100 \%$ \\
\hline
\end{tabular}

Source: DSPA 2007 (www.dspa.be), author's calculations 
Table 3: Predicting Perceived Personal Discrimination in Socio-economic and Civic Domains for Second-Generation Turks and Moroccans (standardized parameter estimates)

Turkish Second Generation

\begin{tabular}{|c|c|c|c|c|c|c|c|}
\hline & & $\begin{array}{l}\text { Socio- } \\
\text { economic }\end{array}$ & $\begin{array}{c}\text { Civic: } \\
\text { Public space }\end{array}$ & $\begin{array}{c}\text { Civic: } \\
\text { Authority }\end{array}$ & $\begin{array}{c}\text { Socio- } \\
\text { economic }\end{array}$ & $\begin{array}{c}\text { Civic: } \\
\text { Public space }\end{array}$ & $\begin{array}{c}\text { Civic: } \\
\text { Authority }\end{array}$ \\
\hline Gender & Women & $-0.39 * *$ & Ns & $-0.65 * *$ & $-0.33 *$ & $-0.31 * *$ & $-0.73 * *$ \\
\hline \multirow[t]{6}{*}{ Socio-economic attainment } & Unemployed & $0.39 * *$ & ns & ns & ns & ns & $-0.14 *$ \\
\hline & Inactive: student & ns & ns & ns & $0.20 * *$ & ns & $-0.18 *$ \\
\hline & Inactive: other & ns & $-0.12 \dagger$ & $-0.17 *$ & ns & ns & ns \\
\hline & Higher educ & ns & ns & ns & ns & ns & ns \\
\hline & Women*Higher educ & $0.27 *$ & na & na & ns & ns & ns \\
\hline & Women*Student & ns & ns & $0.18^{\dagger}$ & ns & $0.34 *$ & $0.23 *$ \\
\hline Local media consumption & Read local news & $0.26 * *$ & $0.19 * *$ & $0.14^{*}$ & ns & ns & ns \\
\hline \multirow{4}{*}{ Local intergroup climate } & Safety threat & $0.19 \dagger$ & $0.21 * *$ & $0.11^{\dagger}$ & ns & $0.19 *$ & ns \\
\hline & Economic threat & ns & ns & $0.12 *$ & $0.21 *$ & ns & ns \\
\hline & Rel group size & ns & ns & ns & $0.19 *$ & ns & ns \\
\hline & Perc. hostility & $0.17+$ & $0.31 * *$ & $0.20 * *$ & $0.21 *$ & $0.29 * *$ & $0.25 * *$ \\
\hline
\end{tabular}

\section{Moroccan Second Generation}

$\dagger: \mathrm{p}<0.1 *: \mathrm{p}<0.05 * *: \mathrm{p}<0.01$ ns: not significant

Fit measures of multigroup model for civic domains (Turks, Moroccans and Belgians): Chi2=103.256 p-value=0.147; RMSEA=0.022; CFI=0.991

Fit measures of multigroup model for socio-economic domain (Turks, Moroccans and Belgians): Chi2=71.028 p-value=0.801; RMSEA=0.0; CFI=1 
Table 4: Predicting Perceived Personal Discrimination in Socio-economic and Civic Domains for Majority Belgians (standardized parameter estimates)

\begin{tabular}{llccc}
\hline & & $\begin{array}{c}\text { Socio- } \\
\text { economic }\end{array}$ & $\begin{array}{c}\text { Civic: } \\
\text { Public space }\end{array}$ & $\begin{array}{c}\text { Civic: } \\
\text { Authority }\end{array}$ \\
\hline Gender & Women & $\mathrm{ns}$ & $\mathrm{ns}$ & $-0.32^{* *}$ \\
& Unemployed & $0.16^{\dagger}$ & $0.14^{\dagger}$ & $\mathrm{ns}$ \\
Socio-economic attainment & Inactive: student & $\mathrm{ns}$ & $0.20^{*}$ & $\mathrm{~ns}$ \\
& Inactive: other & $\mathrm{ns}$ & $\mathrm{ns}$ & $\mathrm{ns}$ \\
& Higher educ & $-0.27^{*}$ & $\mathrm{~ns}$ & $\mathrm{~ns}$ \\
& Women*Higher educ & $\mathrm{ns}$ & $\mathrm{ns}$ & $\mathrm{ns}$ \\
& Women*Student & $\mathrm{ns}$ & $\mathrm{ns}$ & $\mathrm{ns}$ \\
\hline Local media consumption & Read news & $\mathrm{ns}$ & $\mathrm{ns}$ & $\mathrm{ns}$ \\
\hline \multirow{2}{*}{ Local intergroup climate } & Safety threat & $\mathrm{ns}$ & $\mathrm{ns}$ & $0.18 \dagger$ \\
& Economic threat & $\mathrm{ns}$ & $\mathrm{ns}$ & $\mathrm{ns}$ \\
& Rel group size & $\mathrm{ns}$ & $-0.17^{*}$ & $\mathrm{~ns}$ \\
& Perc. hostility & $\mathrm{ns}$ & $\mathrm{ns}$ & $\mathrm{ns}$ \\
\hline
\end{tabular}

$\dagger: \mathrm{p}<0.1 *: \mathrm{p}<0.05 * *: \mathrm{p}<0.01 \mathrm{~ns}:$ not significant

Fit measures are given in Table 3. 
Figure 1. Perceived Personal Discrimination by Men: Percentages by Group and Domain (systematic $=$ frequently, incidental $=$ sometimes $)$

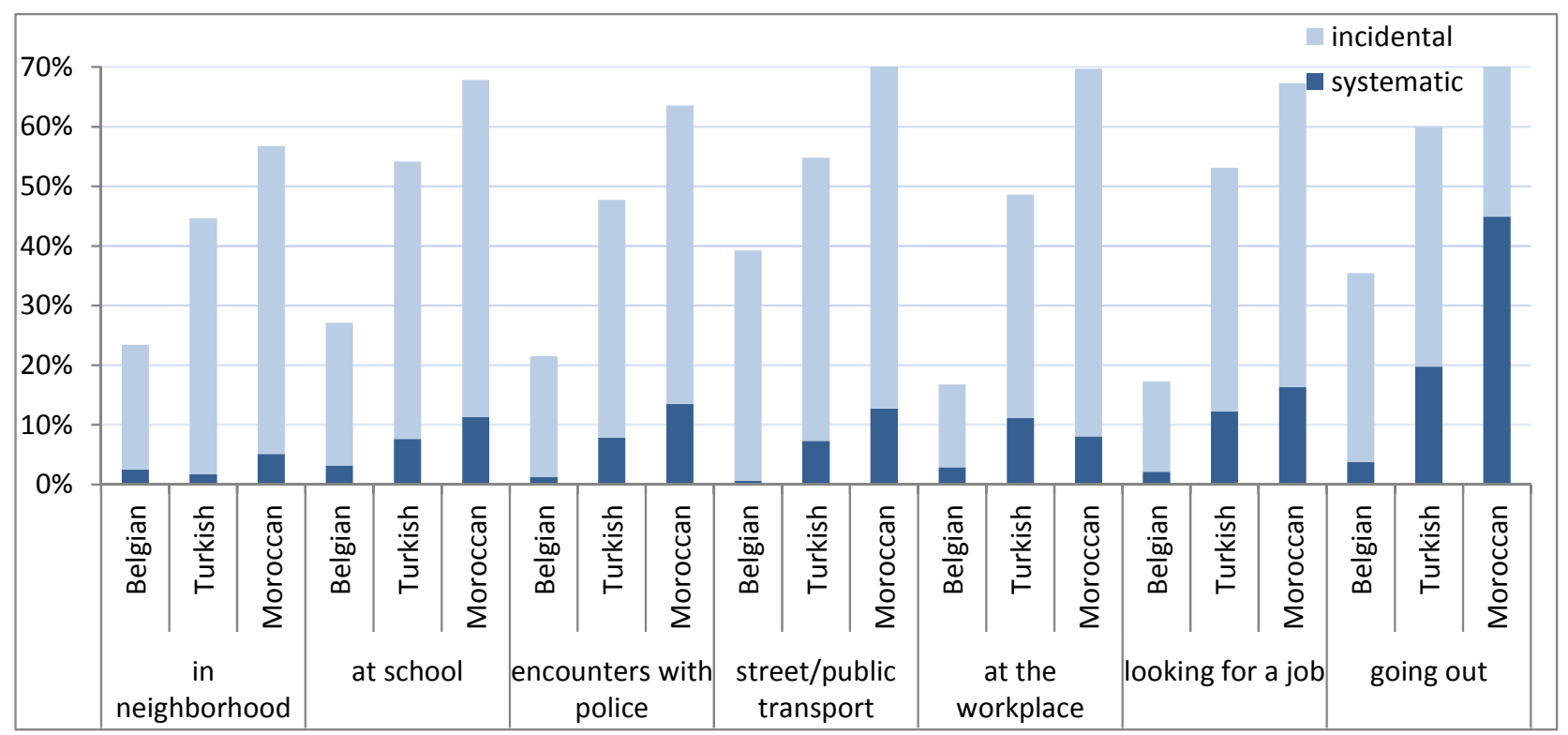

Figure 2. Perceived Personal Discrimination by Women: Percentages by Group and Domain (systematic $=$ frequently, incidental $=$ sometimes)

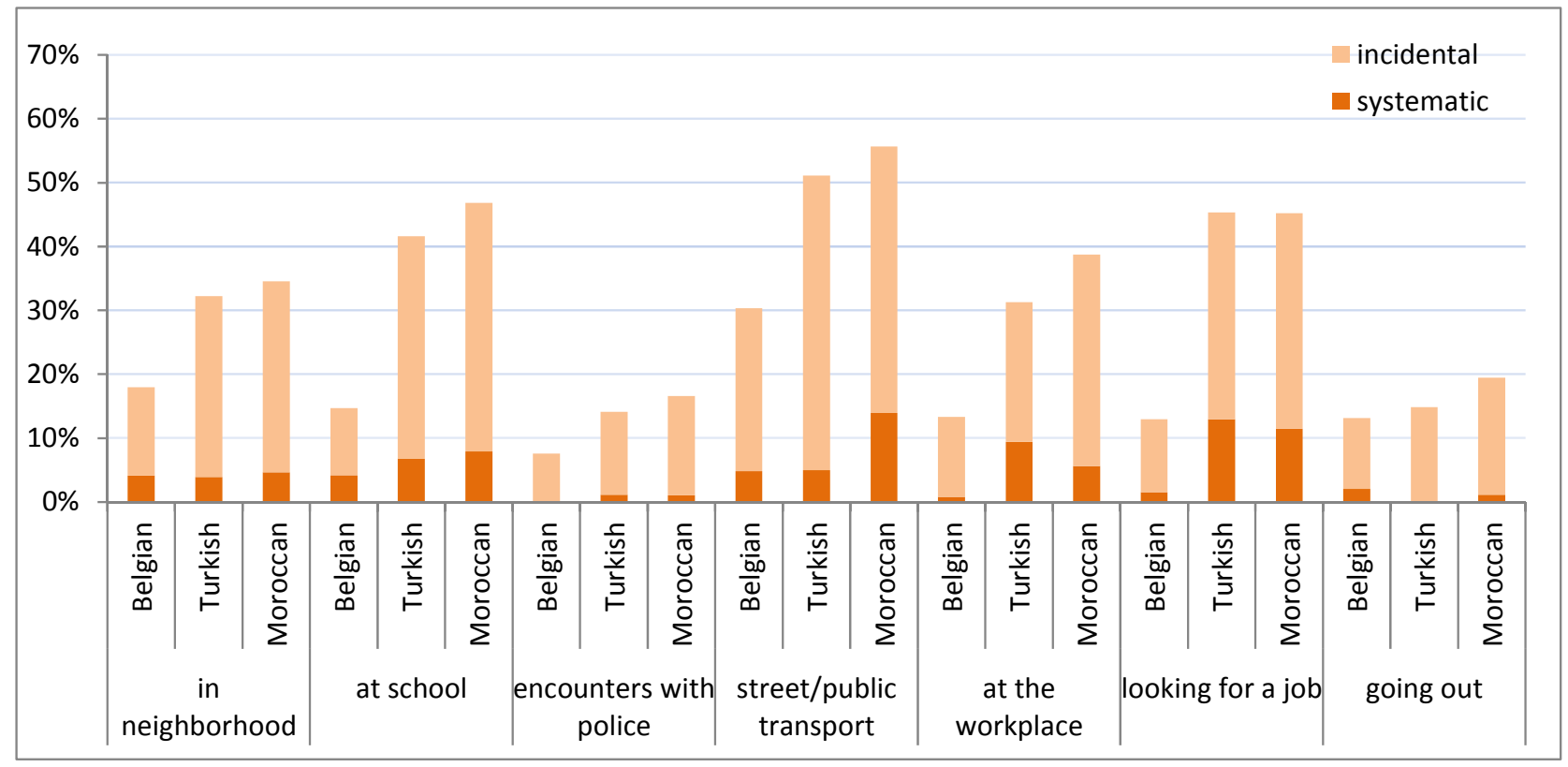

Source: TIES BELGIUM 2007-2008, ISPO-CSCP, University of Leuven. 
Figure 6: Multi-group Measurement Models of Perceived Discrimination in Civic and Socio-economic Domains (unstandardized parameter estimates)

Model 1: Perceived Discrimination in Civic Domains

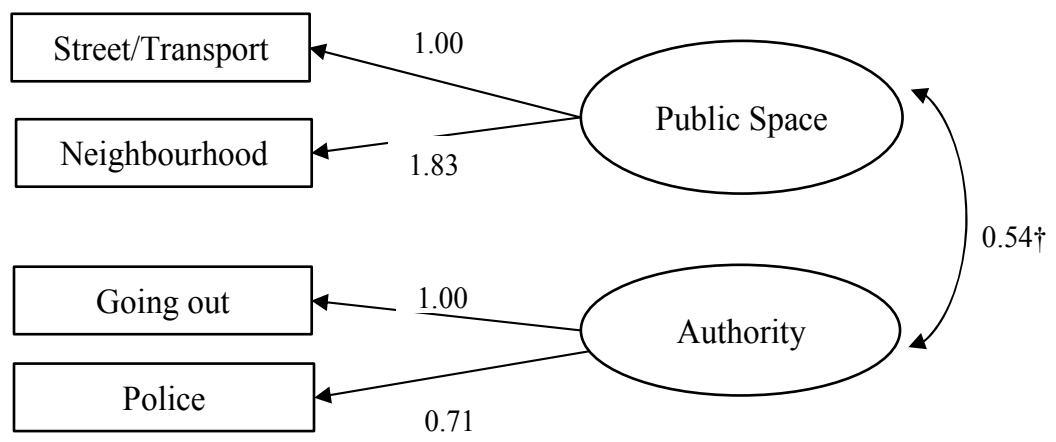

Chi-square $=33.978, \mathrm{df}=23, \mathrm{p}$-value $=0.065, \mathrm{RMSEA}=0.038$
Model 2: Perceived Discrimination in the Socio-economic Domain

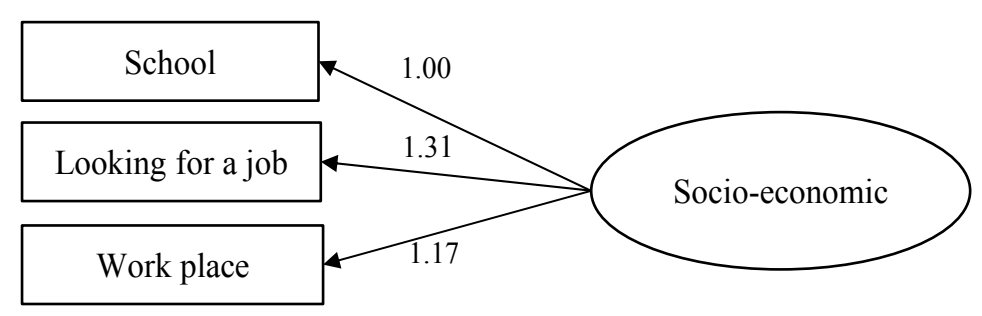

Chi-square $=9.67, \quad \mathrm{df}=16, \quad \mathrm{p}$-value $=0.883, \mathrm{RMSEA}=0$

$\dagger$ Factor covariance was not restrained to be equal across groups. It was 0.54 for minority groups and 0.45 for Belgians.

Both models are estimated using Weighted Least Squares for Categorical Variables (Muthén, 1984) 


\section{APPENDIX I}

\section{Measures of Perceived Personal Discrimination}

Socio-economic Domain

As a secondary school student, how often did you personally experience hostility or unfair treatment because of your origin or background?

Never - Rarely - Occasionally - Regularly - Frequently

When looking for a job, currently or in the past, how often have you personally experienced hostility or unfair treatment because of your origin?

Never - Rarely - Occasionally - Regularly - Frequently

At your workplace, currently or in the past, how often have you personally experienced hostility or unfair treatment because of your origin?

Civic Domain: Public Space

Here are some situations or places. How often did you experience hostility or unfair treatment because of your origin or background in these situations?

a. On the street or on public transport

b. In your neighbourhood

c. When going out or in dancing's, cafés, or restaurants

Never - Rarely - Occasionally - Regularly - Frequently

Civic Domain: Authority

Here are some situations or places. How often did you experience hostility or unfair treatment because of your origin or background in these situations?

In encounters with the police

Never - Rarely - Occasionally - Regularly - Frequently

\section{Predictors of Perceived Personal Discrimination}

Socio-economic Attainment

Employment

Unemployed

Inactive: students

Inactive: other

[Reference category: Employed]

\section{Educational qualifications}

Higher education (i.e., attending or having completed tertiary education)

[Reference category: Less than higher education]

Intergroup Climate

Local media use

Do you sometimes follow the topics listed below in the newspapers, television, radio, or on the Internet? The news about Antwerp local politics

Never - Rarely - Occasionally - Regularly - Frequently

Relative in-group size in one's neighbourhood

When you now think of all the people living in your neighbourhood, how many of them are of [ingroup: Turkish/ Moroccan/ Belgian] origin? 
Almost everybody - More than 75\% - Approximately $75 \%$ - Approximately half - Approximately 25 $\%$ - Less than $25 \%$ - Almost none [reverse coded]

\section{Economic and safety threat}

I am afraid that my living conditions, such as my income and work, will become worse in the near future

Totally agree - Agree - Neither agree nor disagree - Disagree - Totally disagree [reverse coded]

I am afraid that in the near future violence and vandalism in society will increase

Totally agree - Agree - Neither agree nor disagree - Disagree - Totally disagree [reverse coded]

\section{Intergroup hostility}

In general, to what extent would you describe the relationship between people of Belgian origin and people of [Turkish/Moroccan] origin in Antwerp as friendly?

Not friendly at all - Not so friendly - Indifferent - Friendly - Very friendly [reverse coded]

In general, how often do you think that the following groups experience hostility or unfair treatment because of their origin or background? (in-group: Belgians/ Turks/ Moroccans)

Never - Rarely - Occasionally - Regularly - Frequently

TIES BELGIUM 2007-2008, ISPO-CSCP, University of Leuven 


\section{APPENDIX II}

Samples

For the second generation we used simple random samples of persons from a full sampling frame. For the Belgian origin comparison group, we used a stratified sample: we selected them in neighbourhoods proportionately to the number of second generation Turks and Moroccans (from 18 - 35 years) living in that neighbourhood.

Table 4. Interviews in Antwerp

\begin{tabular}{rccc}
\hline & Men & Women & Total \\
\hline Belgian & 158 & 145 & 303 \\
Turkish & 178 & 180 & 358 \\
Moroccan & 118 & 194 & 312 \\
\hline Total & 454 & 519 & 973
\end{tabular}

Response Rates

For the Belgian origin comparison group the overall response rate was $55.76 \%$ and the cooperation rate 69.61 . For the Turkish group the overall response rate $63.48 \%$ was and the cooperation rate $75.05 \%$. For the Moroccan group the overall response rate was $55.9 \%$ and the cooperation rate $69.21 \%$

Table 5. Overall Response Rates in Antwerp

\begin{tabular}{rccc}
\hline & $\begin{array}{c}\text { Num } \\
\text { ber }\end{array}$ & $\begin{array}{c}\text { Overall response } \\
\text { rate }\end{array}$ & $\begin{array}{c}\text { Cooperation } \\
\text { rate }\end{array}$ \\
\hline Interviewed & 966 & $58.44 \%$ & $71.40 \%$ \\
Refusal & 343 & $20.75 \%$ & $25.35 \%$ \\
Not reached & 290 & $17.54 \%$ & $\mathrm{NA}$ \\
Illness & 10 & $0.60 \%$ & $\mathrm{NA}$ \\
Language problems & 14 & $0.85 \%$ & $1.03 \%$ \\
Other & 30 & $1.81 \%$ & $2.22 \%$ \\
SUBTOTAL & 1,653 & $100,00 \%$ & $100,00 \%$ \\
Does not belong to sample & & & $\mathrm{NA}$ \\
frame & 289 & $\mathrm{NA}$ & $100 \%$ \\
\hline TOTAL & 1,942 & $100 \%$ & \\
\hline
\end{tabular}

Source. TIES BELGIUM 2007-2008, ISPO-CSCP, University of Leuven 


\section{APPENDIX III}

Figure 3. Perceived Grounds for Discrimination by the Turkish Second Generation (Percentages)
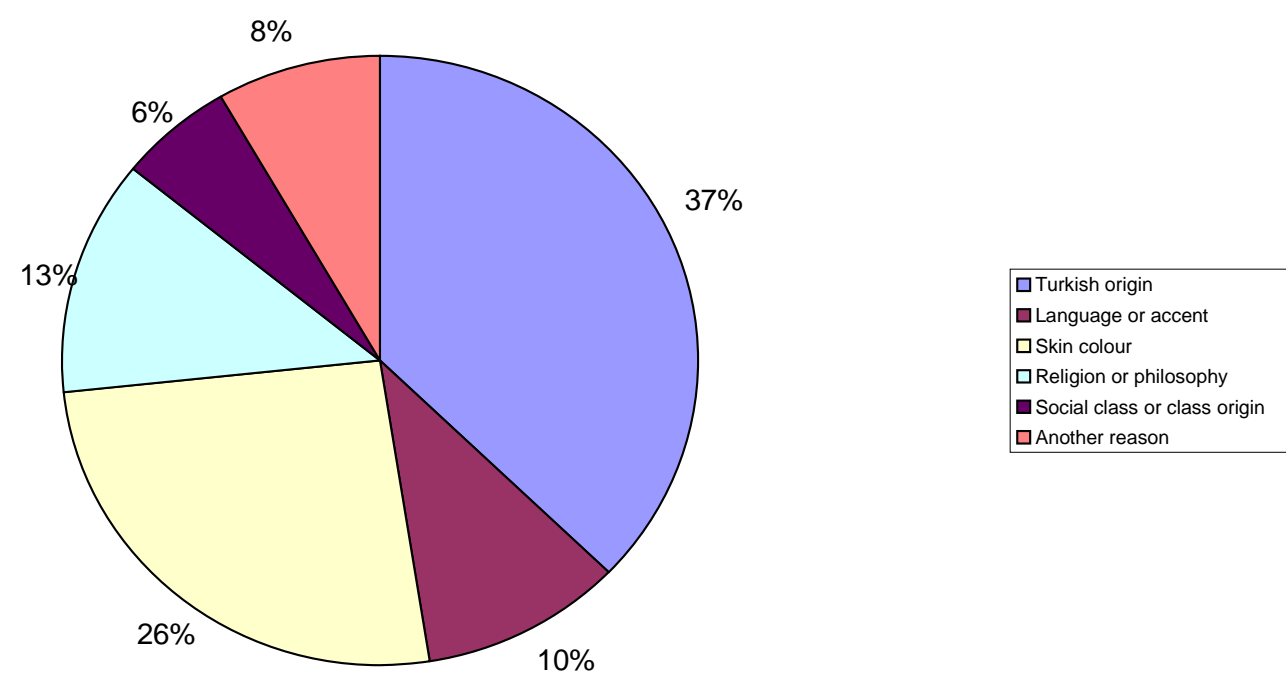

TIES BELGIUM 2007-2008, ISPO-CSCP, University of Leuven 
Figure 4. Perceived Grounds for Discrimination by the Moroccan Second Generation (percentages)
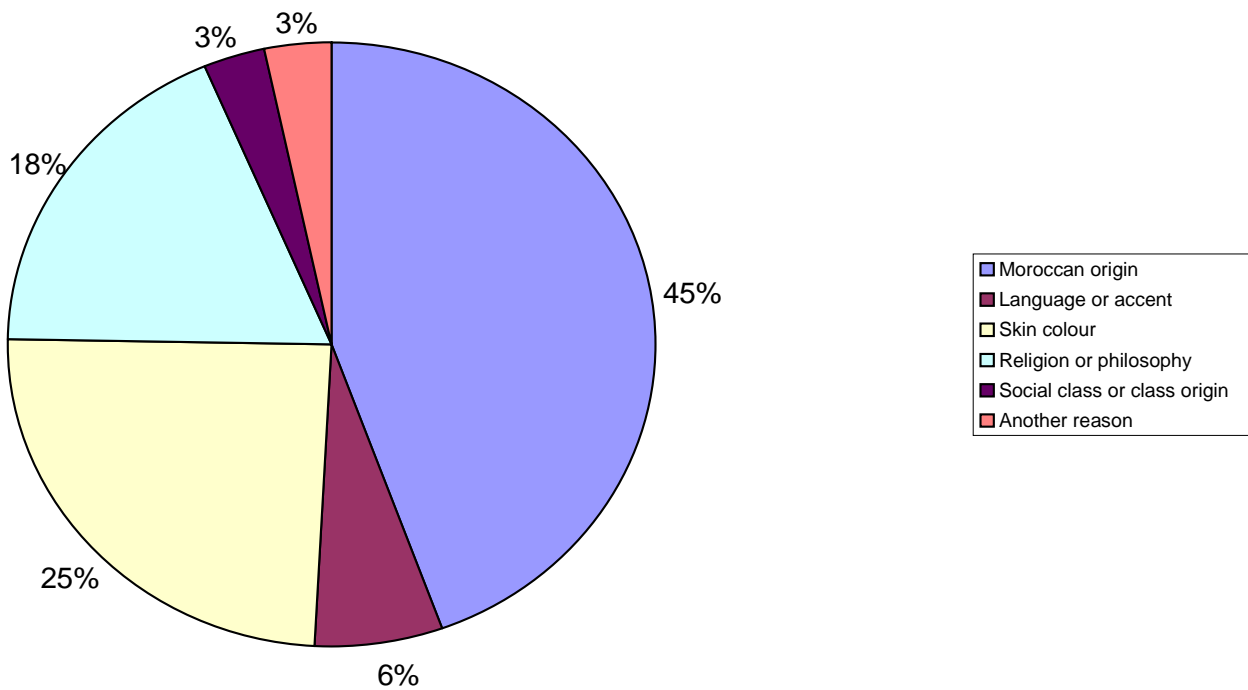

$\square$ Another reason

TIES BELGIUM 2007-2008, ISPO-CSCP, University of Leuven 
Figure 5. Perceived Grounds for Discrimination by Majority Belgians (percentages)
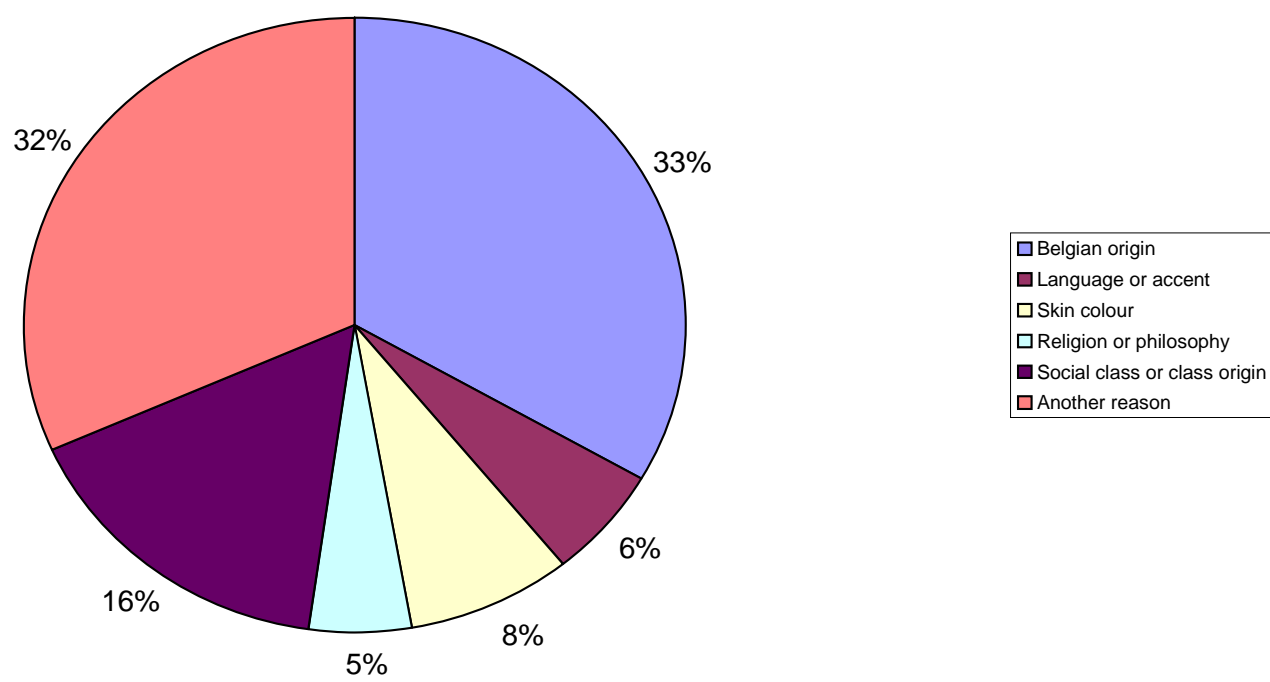